\title{
Ammonia recovery from hydrolyzed human urine by forward osmosis with acidified draw solution
}

\author{
Hannah Ray ${ }^{a b^{*}}$, Francois Perreault ${ }^{\mathrm{a}}$, and Treavor H. Boyer ${ }^{\mathrm{ab}}$ \\ aSchool of Sustainable Engineering and the Built Environment (SSEBE) \\ Arizona State University \\ P.O. Box 873005, Tempe, Arizona, 85287-3005, USA \\ bBiodesign Swette Center for Environmental Biotechnology \\ Arizona State University \\ P.O. Box 873005, Tempe, Arizona, 85287-3005, USA \\ *Corresponding author \\ Tel.: 1-418-6899 \\ E-mail addresses: hgray3@asu.edu (H. Ray).
}

SUPPLEMENTAL MATERIALS

10 pages

3 figures

6 tables 
MATERIALS

2 Materials

3 Microfiltration Pretreatment. Spectrapure microfiltration (MF) systems were used to pretreat

4 the urine. A $1 \mu \mathrm{m}$ sediment filter cartridge (L-SF-MT-1-10) followed by a $0.2 \mu \mathrm{m}$ ZetaZorb

5 sediment filter cartridge (L-SF-ZZ-0.2ABS-10) were used to process the urine after the $\mathrm{pH}$ of the

6 urine was altered. A dual position housings fitting mounting bracket (FA-2STA-10) with a Cole-

7 Parmer Masterflex L/S digital pump with an Easy-Load II pump head were used. All filter

8 diameters were $25.4 \mathrm{~cm}$. The Spectrapure MF membranes were chosen as they were a local,

9 commercially available, cost-effective option that should effectively remove suspended solids

10 and bacteria based on the pore sizes.

12 Forward osmosis and membrane distillation set-ups. Cole-Parmer Acrylic In-Line

13 Flowmeter, 1 GPM Water, 3/8" NPT (F) were used to monitor the flow of the solution in the FO

14 systems. Cole-Parmer console drive, $115 \mathrm{VAC}, 50 / 60 \mathrm{~Hz}$ pumps were used to circulate the

15 solutions in the system. Cole-Parmer Masterflex platinum-cured silicone tubing, L/S 17, was

16 used throughout the FO setup. A Cole-Parmer Polystat recirculator, $17 \mathrm{~L} / \mathrm{min}, 250 \mathrm{~W}$ cooling

17 capacity, 115V $60 \mathrm{~Hz}$ chiller was used for the FO experiments. A Sartorius microbalance was

18 used to track the increase in weight during the experiment to determine the flux of the FO and

19 MD systems. WinWedge, a computer software, connected the balance to Microsoft Excel to log

20 the data. $\mathrm{pH}$ and conductivity readings were taken for all samples using an Orion Dual Star

21 Multiparameter Meter, an Orion 9156BNWP Combination pH probe, and Orion Star A212

22 conductivity probe. 


\section{Experimental methods}

25 Dead-end forward osmosis of fresh urine. The FO membranes were wetted in a 50\%

26 isopropanol $/ 50 \%$ ultrapure water (resistivity $18.2 \Omega$ ) solution for $30 \mathrm{~min}$. The membranes were

27 then transferred into ultrapure water for $10 \mathrm{~min}$. After the $10 \mathrm{~min}$ were completed, the

28 membranes were transferred to fresh ultrapure for an additional $10 \mathrm{~min}$. For all experiments, 450

29 mL of solution was used on each side of the membrane. Initial samples were taken from the bulk

30 solutions. The solutions were then poured into membrane setup and the timer was started. The

31 initial heights of the solutions were marked. At $1 \mathrm{~h}$, the rise or fall of the solution was recorded

32 using a measuring tape, and a $20 \mathrm{~mL}$ sample was taken from each side. The new liquid heights

33 were marked.

35 Cleaning procedure. The membrane systems were cleaned immediately after each experiment 36 using the following procedure: tap water rinse, 10\% bleach for $15 \mathrm{~min}$, tap water rinse, $5 \mathrm{mM}$

37 EDTA for 15 min, tap water rinse, DI water with $\mathrm{NaOH}$ added to increase the $\mathrm{pH}$ to 11 for 15 38 min, tap water rinse, and three DI water rinses each for $10 \mathrm{~min}$.

Analytical methods. For the urea analysis by assay kit, a $1000 \mathrm{mg} / \mathrm{L}$ standard was used to

41 increase the calibration curve from 500 to $1000 \mathrm{mg} / \mathrm{L}$. Three check standards were used for every

42 plate reading: 800, 500, and $100 \mathrm{mg} / \mathrm{L}$ in duplicate to ensure accuracy. Ammonia and urea results

43 were confirmed through analysis of Total Nitrogen (TN). Four check standards were used for

44 each TOC/TN run: TN 5, TN 1, TOC 10, and TOC $5 \mathrm{mg} / \mathrm{L}$. The criteria for accuracy was within

$4510 \%$ of check standards, and the criteria for precision was samples run in duplicate. 


\section{FIGURES}

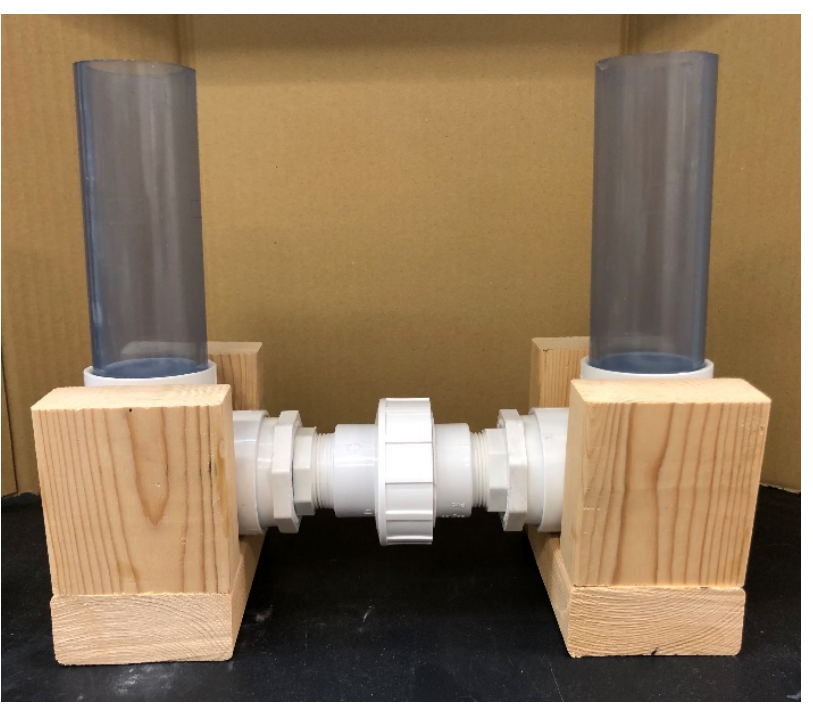

49 Figure S1. Picture detailing the dead-end forward osmosis (FO) setup that was used for

50 determination of urea transfer across the FO membrane.

51

52

53

54

55

56

57

58

59 

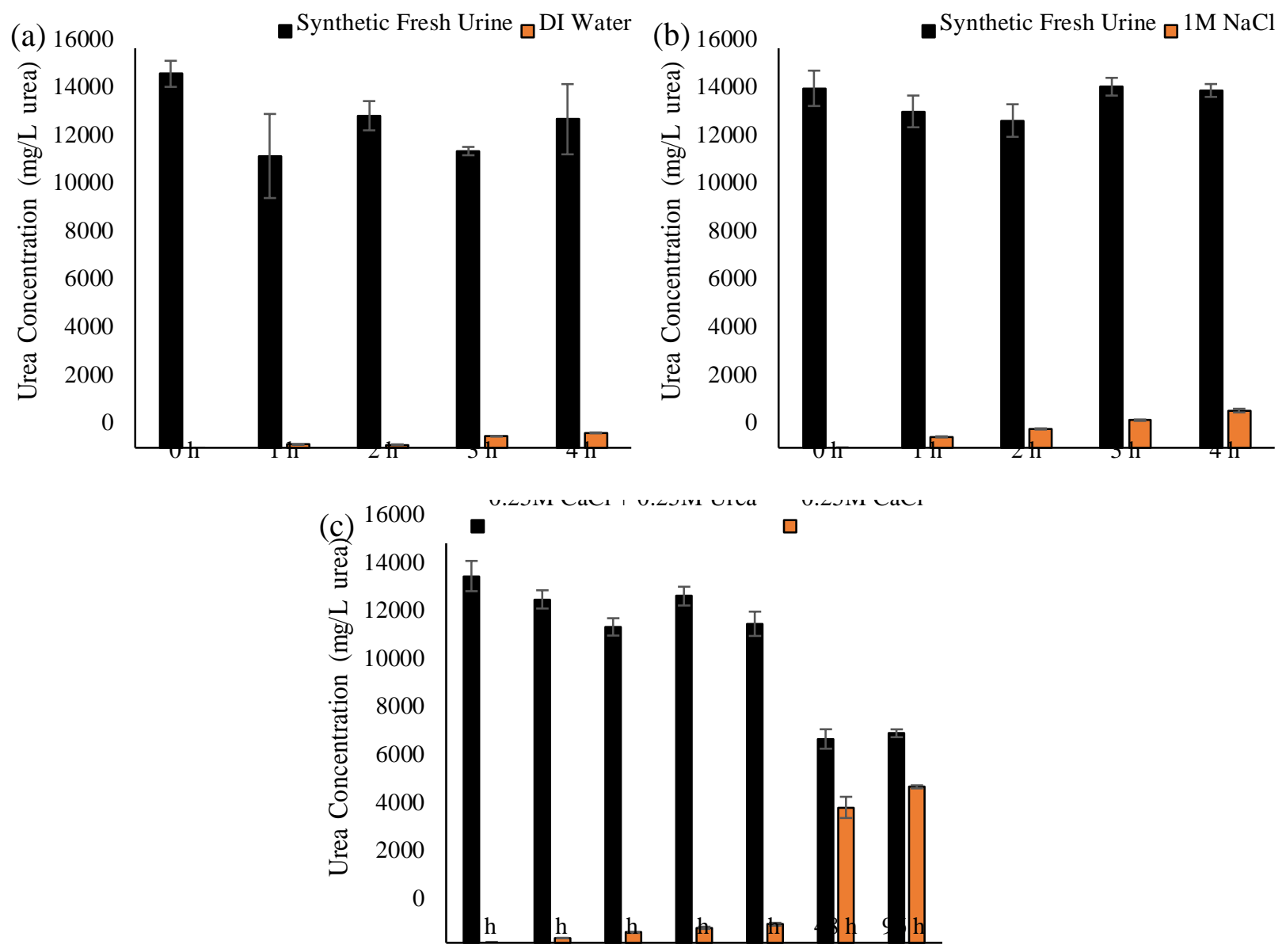

Figure S2. Duplicate data for the dead-end FO evaluation of low molecular weight neutral compound transfer where urea was used as the model compound. The urea concentration over time for (a) condition 1: DI water and synthetic fresh urine, (b) condition 2: synthetic fresh urine and $1 \mathrm{M} \mathrm{NaCl}$, and (c) condition 3: $0.25 \mathrm{M} \mathrm{CaCl}+0.25 \mathrm{M}$ urea and $0.25 \mathrm{CaCl}$. Error bars represent + -- one standard deviation. 

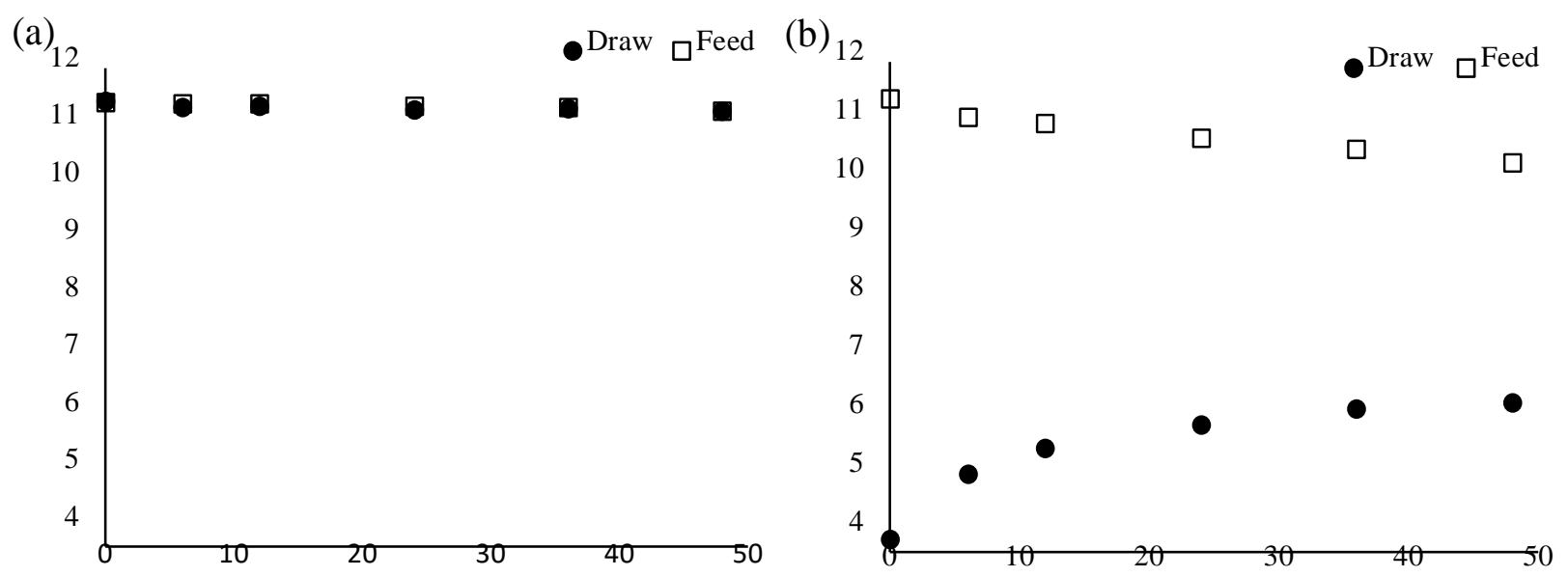

Figure S3. The pH of both the feed and draw solutions over time. (a) $\mathrm{NaCl}$ draw solution condition where both the feed and draw solutions were $\mathrm{pH}$ adjusted to 11.5 which explains the overlap of the feed and draw data points. (b) $\mathrm{KH}_{2} \mathrm{PO}_{4}$ draw solution condition where the feed was $\mathrm{pH}$ adjusted to 11.5 and the draw had a natural starting $\mathrm{pH}$ of 4.2. The graphed values are averages for duplicate experiments. 


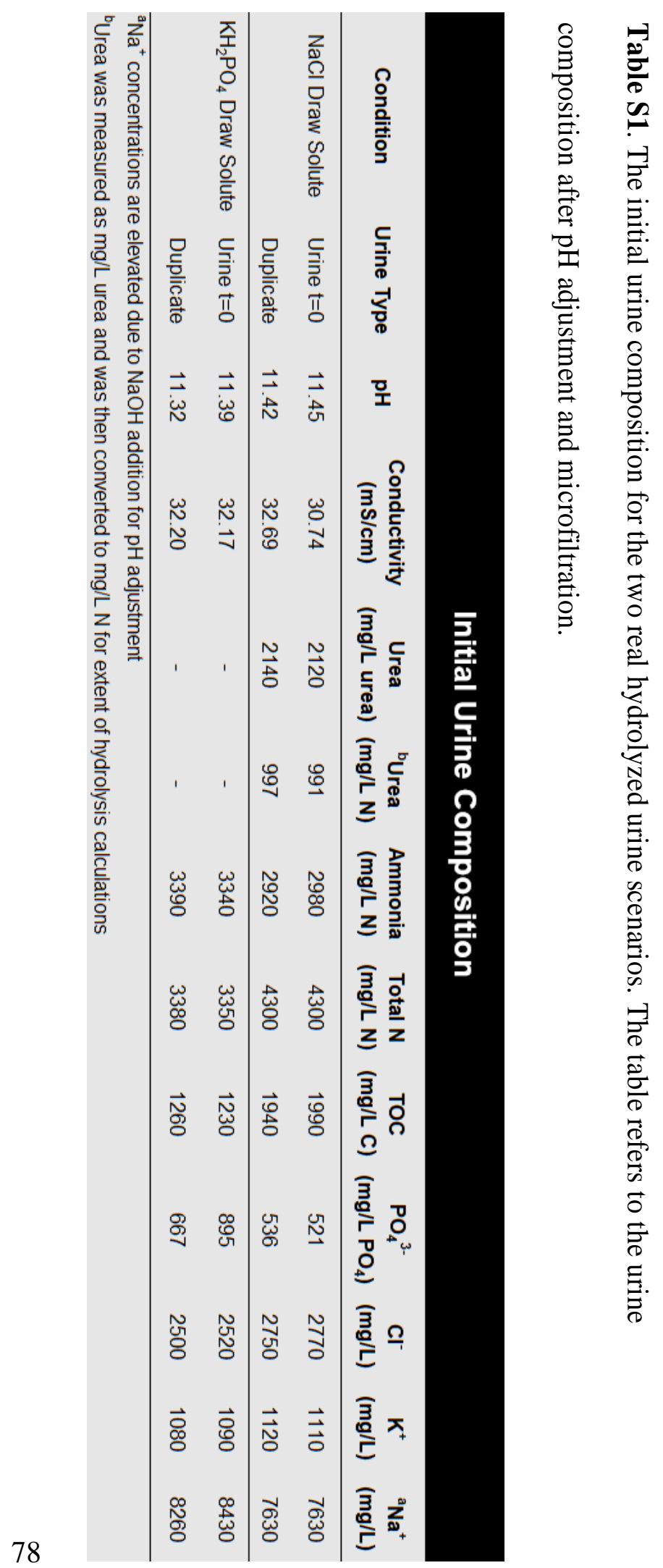


79 Table S2. The composition of the synthetic urine used for all synthetic urine experiments

\begin{tabular}{cc}
\hline \multicolumn{2}{c}{ Synthetic fresh urine composition } \\
\hline Compound & Concentration $(\mathbf{g} / \mathbf{L})$ \\
\hline $\mathrm{Urea}$ & 15.0075 \\
$\mathrm{NaCl}$ & 2.5715 \\
$\mathrm{Na} \mathrm{SO}_{4}$ & 2.1305 \\
$\mathrm{KCl}$ & 2.982 \\
$\mathrm{MgCl}_{2} \cdot 6 \mathrm{H}_{2} \mathrm{O}$ & 0.813 \\
$\mathrm{NaH}_{2} \mathrm{PO}_{4}$ & 2.3995 \\
$\mathrm{CaCl}_{2} \cdot 2 \mathrm{H}_{2} \mathrm{O}$ & 0.588 \\
$\mathrm{pH}$ & 6 \\
\hline${ }^{2}$ & $6 \mathrm{The} \mathrm{pH}$ of the synthetic fresh urine was adjusted to 6 using sodium hydroxide
\end{tabular}

84 Table S3. The initial $(t=0)$ and final $(t=48 \mathrm{~h})$ conductivities for both the $\mathrm{NaCl}$ and $\mathrm{KH}_{2} \mathrm{PO}_{4}$

85 draw solution conditions for ammonia recovery by forward osmosis.

\begin{tabular}{ccccc}
\hline \multirow{2}{*}{ Condition } & \multicolumn{2}{c}{ Initial and Final Conductivity } \\
& Solution $\mathbf{t}=\mathbf{0 ~} \mathbf{h}$ & $\begin{array}{c}\text { Conductivity } \\
(\mathbf{m S / c m})\end{array}$ & Solution $\mathbf{t = 4 8} \mathbf{h}$ & $\begin{array}{c}\text { Conductivity } \\
\mathbf{( m S / c m})\end{array}$ \\
\hline \multirow{2}{*}{$\mathrm{NaCl}$ Draw Solute } & Urine & 30.74 & Urine & 46.14 \\
& Duplicate & 32.69 & Duplicate & 45.44 \\
\cline { 2 - 5 } & Draw & 124.1 & Draw & 79.63 \\
& Duplicate & 134.5 & Duplicate & 82.83 \\
\hline $\mathrm{KH}_{2} \mathrm{PO}_{4}$ Draw Solute & Urine & 32.17 & Urine & 41.67 \\
& Duplicate & 32.20 & Duplicate & 41.69 \\
\cline { 2 - 5 } & Draw & 81.89 & Draw & 75.05 \\
& Duplicate & 81.93 & Duplicate & 75.61 \\
\hline
\end{tabular}

86

87

88 
89 Table S4: The dead-end forward osmosis urea transfer data for the three different conditions.

90 Figure 2 shows the results in graphed form. All units are $\mathrm{mg} / \mathrm{L}$ of urea.

\begin{tabular}{|c|c|c|c|c|c|c|c|c|}
\hline \multicolumn{9}{|c|}{ Dead-end FO Urea Transport } \\
\hline Condition & Solution & 0 (h) & 1 (h) & 2 (h) & 3 (h) & 4 (h) & $48(h)$ & $96(h)$ \\
\hline \multirow[t]{2}{*}{ 1: Urine - DI water } & Urine & 14700 & 14500 & 14300 & 14500 & 14200 & - & - \\
\hline & DI water & - & 257 & 396 & 468 & 522 & - & - \\
\hline \multirow[t]{2}{*}{ 2: Urine - $1 \mathrm{M} \mathrm{NaCl}$} & Urine & 14800 & 14500 & 14200 & 14000 & 13900 & - & - \\
\hline & $1 \mathrm{M} \mathrm{NaCl}$ & - & 430 & 776 & 1130 & 1370 & - & - \\
\hline \multirow[t]{2}{*}{ 3: $\mathrm{CaCl}_{2}+$ urea $-\mathrm{CaCl}_{2}$} & $\mathrm{CaCl}_{2}+$ urea & 14000 & 14000 & 13700 & 13 & 12200 & 8700 & 6700 \\
\hline & $\mathrm{CaCl}_{2}$ & - & 185 & 350 & 553 & 868 & 4590 & 7970 \\
\hline
\end{tabular}

95 Table S5. The duplicate dead-end forward osmosis urea transfer data for the three different

96 conditions. Figure S2 shows the results in graphed form All units are mg/L of urea.

\section{Duplicate Dead-end FO Urea Transport}

\begin{tabular}{|c|c|c|c|c|c|c|c|c|}
\hline \multicolumn{9}{|c|}{ Duplicate Dead-end FO Urea Transport } \\
\hline Condition & Solution & 0 (h) & 1 (h) & 2 (h) & 3 (h) & 4 (h) & $48(h)$ & $96(h)$ \\
\hline \multirow[t]{2}{*}{ Urine - DI } & Urine & 1400 & 11700 & 13300 & 11900 & 13200 & - & - \\
\hline & DI & - & 127 & 125 & 459 & 598 & - & - \\
\hline \multirow[t]{2}{*}{ Urine - $1 \mathrm{M} \mathrm{NaCl}$} & Urine & 14400 & 13500 & 13100 & 14500 & 14300 & - & - \\
\hline & $1 \mathrm{M} \mathrm{NaCl}$ & - & 440 & 755 & 1100 & 1490 & - & - \\
\hline \multirow[t]{2}{*}{$\mathrm{CaCl}_{2}+$ urea $-\mathrm{CaCl}_{2}$} & $\mathrm{CaCl}_{2}+$ urea & 14688 & 13800 & 12700 & 13900 & 12800 & 8200 & 8400 \\
\hline & $\mathrm{CaCl}_{2}$ & - & 196 & 410 & 600 & 742 & 5400 & 6200 \\
\hline
\end{tabular}


102 Table S6: A comparison of various draw solutes depicting their relative costs and considerations

\begin{tabular}{|c|c|c|c|c|}
\hline \multicolumn{5}{|c|}{ Comparison of Various Draw Solutes } \\
\hline Draw Solute & Cost $^{\mathrm{a}}$ & pH in Water & Solubility in Water & Considerations $^{b, c}$ \\
\hline $\mathrm{KH}_{2} \mathrm{PO}_{4}$ & $\$ 0.4 / \mathrm{kg}$ & 4.5 & $25 \mathrm{~g} / 100 \mathrm{~mL}$ at $25^{\circ} \mathrm{C}$ & High osmotic pressure, high reverse salt flux $\left(\mathrm{K}^{+}\right)$, low water solubility \\
\hline $\mathrm{MgSO}_{4}$ & $\$ 0.06 / \mathrm{kg}$ & $5.5-6.5$ & $30 \mathrm{~g} / 100 \mathrm{~mL}$ at $20^{\circ} \mathrm{C}$ & low cost, low water solubility \\
\hline $\mathrm{NH}_{4} \mathrm{H}_{2} \mathrm{PO}_{4}$ & $\$ 0.6 / \mathrm{kg}$ & $3.8-4.4$ & $40.4 \mathrm{~g} / 100 \mathrm{~mL}$ at $25^{\circ} \mathrm{C}$ & High osmotic pressure, high cost, low water flux \\
\hline$\left(\mathrm{NH}_{4}\right)_{2} \mathrm{SO}_{4}$ & $\$ 0.12 / \mathrm{kg}$ & 5.5 & $76.4 \mathrm{~g} / 100 \mathrm{~mL}$ at $25^{\circ} \mathrm{C}$ & High osmotic pressure, high water solubility, low cost \\
\hline $\mathrm{KNO}_{3}$ & $\$ 0.6 / \mathrm{kg}$ & 6.2 & $35.7 \mathrm{~g} / 100 \mathrm{~mL}$ at $25^{\circ} \mathrm{C}$ & High cost, high reverse salt flux $\left(\mathrm{K}^{+}\right)$ \\
\hline $\mathrm{NH}_{4} \mathrm{NO}_{3}$ & $\$ 0.2 / \mathrm{kg}$ & 5.25 & $213 \mathrm{~g} / 100 \mathrm{~mL}$ at $25^{\circ} \mathrm{C}$ & Low cost, high reverse salt flux $\left(\mathrm{NH}_{4}^{+}\right.$and $\left.\mathrm{NO}_{3}{ }^{-}\right)$ \\
\hline
\end{tabular}

